Article

\title{
About the Possibility of Disposal of HLRW in Deep Boreholes in Germany
}

\author{
Guido Bracke ${ }^{1, *}$, Frank Charlier ${ }^{2}$, Axel Liebscher ${ }^{3}$, Frank R. Schilling ${ }^{4}$ and Thomas Röckel ${ }^{5}$ \\ 1 Final Disposal Department, GRS gGmbH, Schwertnergasse 1, 50667 Cologne, Germany \\ 2 RWTH Aachen, Nukleare Entsorgung und Techniktransfer (NET), D-52062 Aachen, Germany; \\ charlier@net.rwth-aachen.de \\ 3 Helmholtz Centre Potsdam, GFZ German Research Centre for Geosciences, Telegrafenberg, \\ 14473 Potsdam, Germany; axel.liebscher@gfz-potsdam.de \\ 4 KIT Karlsruher Institute of Technology-Technical University Karlsruhe, Institute of Applied Geosciences, \\ Adenauerring 20b, 76131 Karlsruhe, Germany; frank.schilling@kit.edu \\ 5 Piewak \& Partner, Jean-Paul-Str. 30, 95444 Bayreuth, Germany; thomas.roeckel@piewak.de \\ * Correspondence: guido.bracke@grs.de; Tel.: +49-221-206-8608
}

Received: 28 April 2017; Accepted: 10 July 2017; Published: 18 July 2017

\begin{abstract}
Using deep boreholes for the final disposal of high-level radioactive waste (HLRW) can take advantage of multiple geologic barriers as safety features and aims for the safe containment of radionuclides by containment-providing rock zones (CPRZ). The great depth efficiently prolongs or hinders radionuclide transport and also impedes proliferation. Finally, there may be a time benefit with regard to technical implementation and costs. Due to the phase-out from nuclear energy in Germany the number of boreholes could be less than 100. A simplified, generic safety concept, and the requirements for the diameter of boreholes and containers are derived in this paper. Furthermore, the operational safety of emplacement, the retrieval of waste and sealing of the boreholes is discussed. It is outlined that boreholes can be sealed quickly and over long distances with proven technologies, for example, using the creep properties of salt rock formations. This concept is assessed for its compliance with the safety requirements of the German Federal Ministry for the Environment, Nature Conservation, Building and Nuclear Safety (BMUB), and the requirements and criteria for site selection defined by the German commission on "Storage of high-level radioactive waste". The retrievability of HLRW is assessed to be technically feasible based on today's knowledge, but recoverability after closure cannot be guaranteed for long time spans. Further developments in details of the concept of deep borehole disposal (DBD), a demonstration of its technical feasibility and an assessment of operational and long-term safety are still necessary to make DBD an approved option.
\end{abstract}

Keywords: high-level radioactive waste; deep boreholes; final disposal; safety analysis

\section{Introduction}

The disposal of high-level radioactive waste (HLRW) using deep boreholes in geological formations (salt rock) had been previously considered in Germany a long time ago [1] but was not pursued then. Furthermore, the safety requirements of the German Federal Ministry for the Environment, Nature Conservation, Building and Nuclear Safety (BMUB) [2] were designed for a geological underground mine.

Deep borehole disposal (DBD) may offer some advantages such as a better containment due to greater depth, faster disposal and lower costs. It is currently under discussion in the USA for Sr-capsules [3,4] and vitrified waste [5] by the Department of Energy, respectively, in the UK [6], and, recently as an option, in Germany [7]. 
The German Commission on "Storage of high-level radioactive waste", which was active from 2014 to 2016 [8], requested a study addressing several questions on DBD [9]. After discussion, DBD was recommended as the only alternative disposal option which should be observed.

In the following paper an overview is presented of the concept of HLRW disposal in deep boreholes based on results of [9]. The DBD concept is discussed with regard to its compatibility with recommendations of the Commission and the safety requirements of the BMUB [2].

\section{Volume of HLRW in Germany}

The volume of HLRW is limited in Germany due to the phase-out of nuclear energy in 2022. The waste forms are mainly spent fuel elements from power reactors (approximately 35,000 pieces, approximately $7600 \mathrm{~m}^{3}$ as fuel rods), canisters with vitrified waste from reprocessing (approximately 8000 pieces, approximately $2000 \mathrm{~m}^{3}$ ) and some spent fuel elements from research reactors (approximately $2000 \mathrm{~m}^{3}$ ).

\section{Generic Concept for Deep Borehole Disposal}

A generic concept for deep borehole disposal (DBD) should show the isolation of the high-level radioactive waste from the biosphere (subject of protection) in the long term. Technical feasibility and operational safety should be given and have to be demonstrated.

\subsection{Requirements for the Generic Concept for DBD}

The great depth which can be reached by boreholes can contribute to a safe containment if overlying sedimentary rocks (such as, e.g., salt, clay rocks, etc.) provide additional geological barriers (multiple barrier concept). The large distance of the disposed-of waste from the surface is also expected to ensure long migration times for radionuclides released from the waste form to human beings and subjects of protection (e.g., groundwater, biosphere). The expected time period for keeping a single borehole open for waste emplacement is considerably shorter than for a mined geological repository, so proliferation risks can be assumed to be much lower.

General requirements for the presented generic concept for DBD were:

- $\quad$ The concept should provide multiple barriers.

- The appropriate lithology should be available in Germany.

- The disposal of canisters with vitrified waste and spent fuel rods should be technically feasible. Other waste is not considered here.

- The retrieval of waste should be possible.

- The concept should also allow monitoring during the operational and post-closure phases.

\subsection{Multiple-Barrier Concept}

The multiple, independent geological barriers can be formed by, for example, clay and salt layers of appropriate dimensions. Together with seals they provide the main safety functions of the generic concept. This means that boreholes have to be sealed effectively within these barriers to restore the functionality of the barriers. Furthermore, deep, very slow groundwater movement is required at great depths that ideally restricts radionuclide migration to diffusion alone.

The generalized concept intends disposal in the geological bedrock (most likely crystalline rock as other rock types may not be fully supported by the mineral-framework, and may therefore develop geopressured fluids), which should be overlain by at least two redundant or diverse geological barriers. Ideally, an additional geological feature-such as an underpressured reservoir-can act as gas trap below these barriers.

The minimum depth for DBD is set at $1500 \mathrm{~m}$, with a maximum depth of $3500 \mathrm{~m}$. This depth will facilitate location of sites in Germany with several independent geological barriers, exclude with greater certainty glacial impacts on barriers and waste, and risks involved with proliferation. 
The maximum depth should be optimized by assessing state-of-the-art drilling, disposal technology, and the outcome of safety analyses. Vertical borehole and inclined boreholes, as well as multiple and deviating boreholes, are possible $[10,11]$. The generic concept with a vertical borehole is depicted schematically in Figure 1.

Possible geological barriers overlying the disposal zone (designated zone) are:

Clay rock: Bedded clay which can ensure retardation and containment. Figure 1 shows an alternating sequence of clay and sandstone.

Salt rock: Bedded salt with high sealing capacity and self-sealing ability based on its visco-plastic characteristics. Figure 1 shows bedded salt.

These barriers should be combined. At least two independent barriers should be available.

A further possible feature would be porous rock (e.g., sandstone) acting as a trap for gases which could be released from the disposal zone. Figure 1 shows a sandstone formation below the salt layer acting as a gas trapping reservoir. Preferentially, this porous rock is within a depleted (underpressured) reservoir. Reservoirs have demonstrated tightness over timeframes of several million years. The underpressure in this reservoir would create an artificial sink for rising fluids or gases.

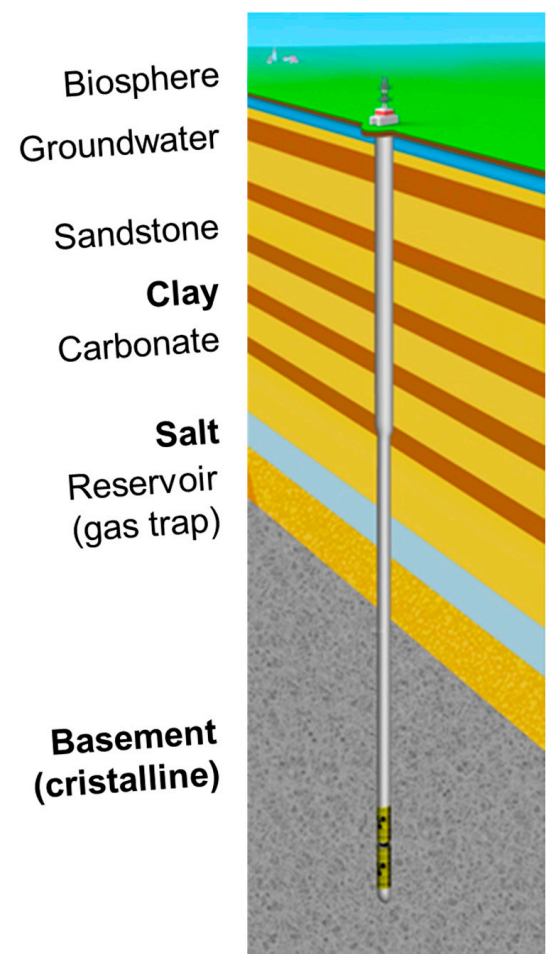

Figure 1. Concept for borehole disposal in deep geological formations (example).

This concept complies regarding the barriers with the safety requirements of the BMUB [2] and the requirements and criteria for site selection defined by the German commission on "Storage of high-level radioactive waste" [8].

There is also a requirement which excludes disposal in rock zones exhibiting recent or young groundwater. This requires the presence of ancient groundwater. If a salinity gradient and a deep brine is present this can be seen as an additional barrier [12].

\subsection{Exploration}

Such geological settings occur naturally in Germany and can be found undisturbed in several places. Clearly, geological exploration is necessary to find and characterize a specific site. This can be performed using a number of standard technologies which include geological, geophysical 
(e.g., seismic), and geochemical exploration, as well as exploration boreholes with logging and coring. Exploration boreholes may be used at later stages for monitoring or can be developed as boreholes for disposal.

\subsection{Technology: Container and Casing}

Containers have to withstand the geomechanical and geochemical conditions experienced during disposal operations. If the recovery of containers is intended for a certain period of time beyond disposal operations, the container should also be able to withstand conditions in the disposal zone. The latter is a design requirement for the canisters which may be achieved by wall thickness allowance or by material selection.

To assess the technical feasibility of a DBD with the option of retrievability, a Deep Borehole Container-Retrievable (DBC-R) was drafted using austenitic steel (Figure 2). The size of the container was derived from the diameter of the canisters with vitrified waste $(0.435 \mathrm{~m})$, which are not pressure-resistant due to a head space, and the length of the fuel rods from spent fuel elements (approximately $4.5 \mathrm{~m}$ ). This assumes that one container should suit all waste types. The length of the DBC-R is about $5.6 \mathrm{~m}$. The DBC-R can take three canisters or an assembly of rods from spent fuel elements. Repacking of the spent fuel elements is anticipated for any disposal concept.

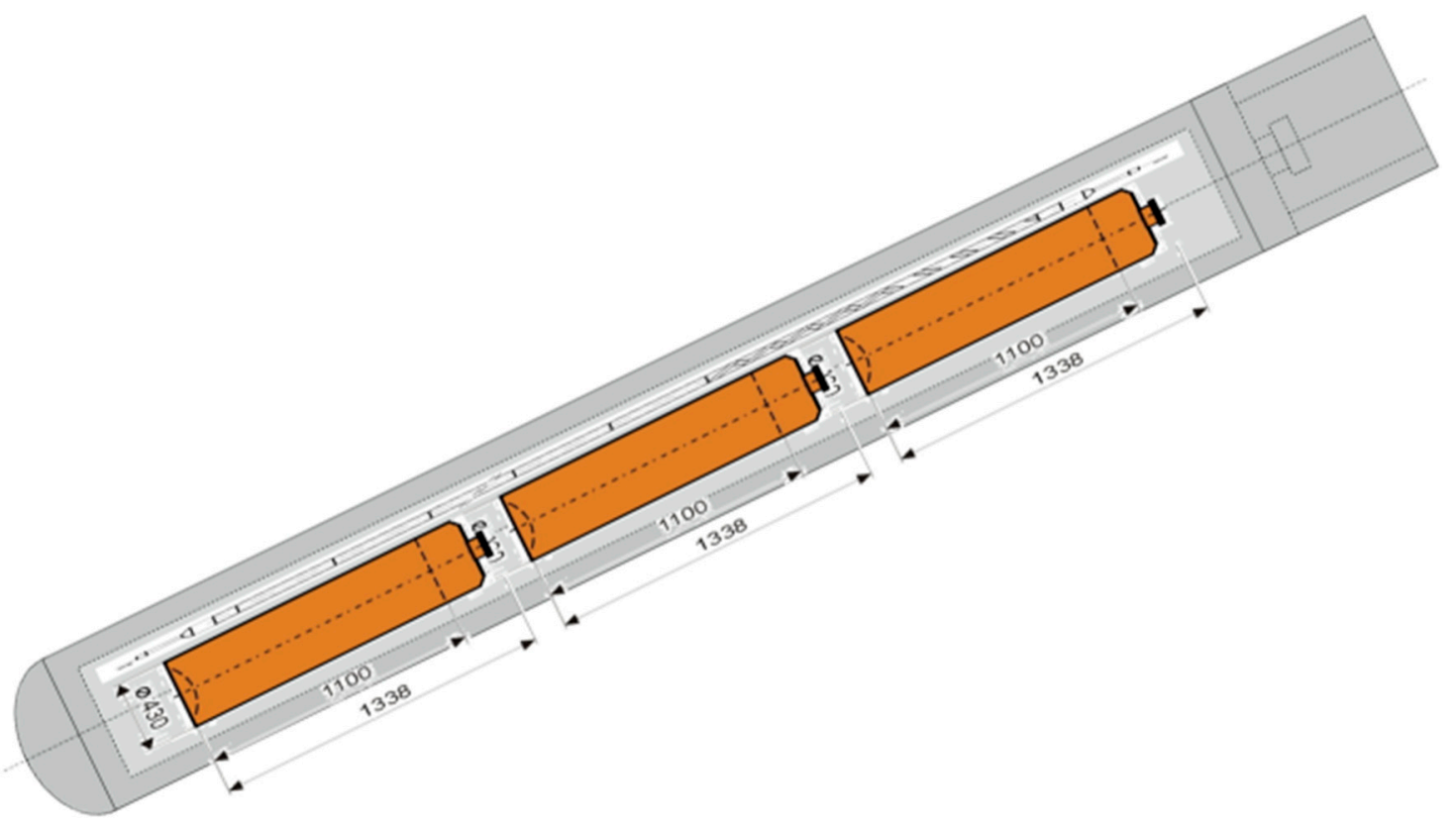

Figure 2. Deep Borehole Container-Retrievable (DBC-R) with three canisters and one rod for illustration (not to scale).

The thickness of the wall of the DBC-R (and therefore the diameter) increases with vertical stacking and disposal depth, but a wall thickness of $4.5 \mathrm{~cm}$ could be sufficient for disposal down to $3500 \mathrm{~m}$ in depth. The diameter of the DBC-R is at minimum about $55 \mathrm{~cm}$ with allowance for temperature and some corrosion.

Based on the diameter of the DBC-R the total resulting outer diameter of the casing is $70 \mathrm{~cm}$ considering a wall thickness of the casing of approximately $6 \mathrm{~cm}$ (see chapter borehole design) and some play for container within the well. Therefore a borehole diameter of $75 \mathrm{~cm}$ including some allowance for uncertainties should be considered for a depth of $3500 \mathrm{~m}$ (Figure 3).

Further optimization of the canister's design and material is expected. By varying the thickness or material of the wall, corrosion or other degradation mechanisms can be countered. 
Using these numbers, 31 boreholes would be sufficient in the best case for disposal of the HLRW from Germany (Table 1). This number of boreholes will likely increase for monitoring reasons and not every borehole will be successfully completed.

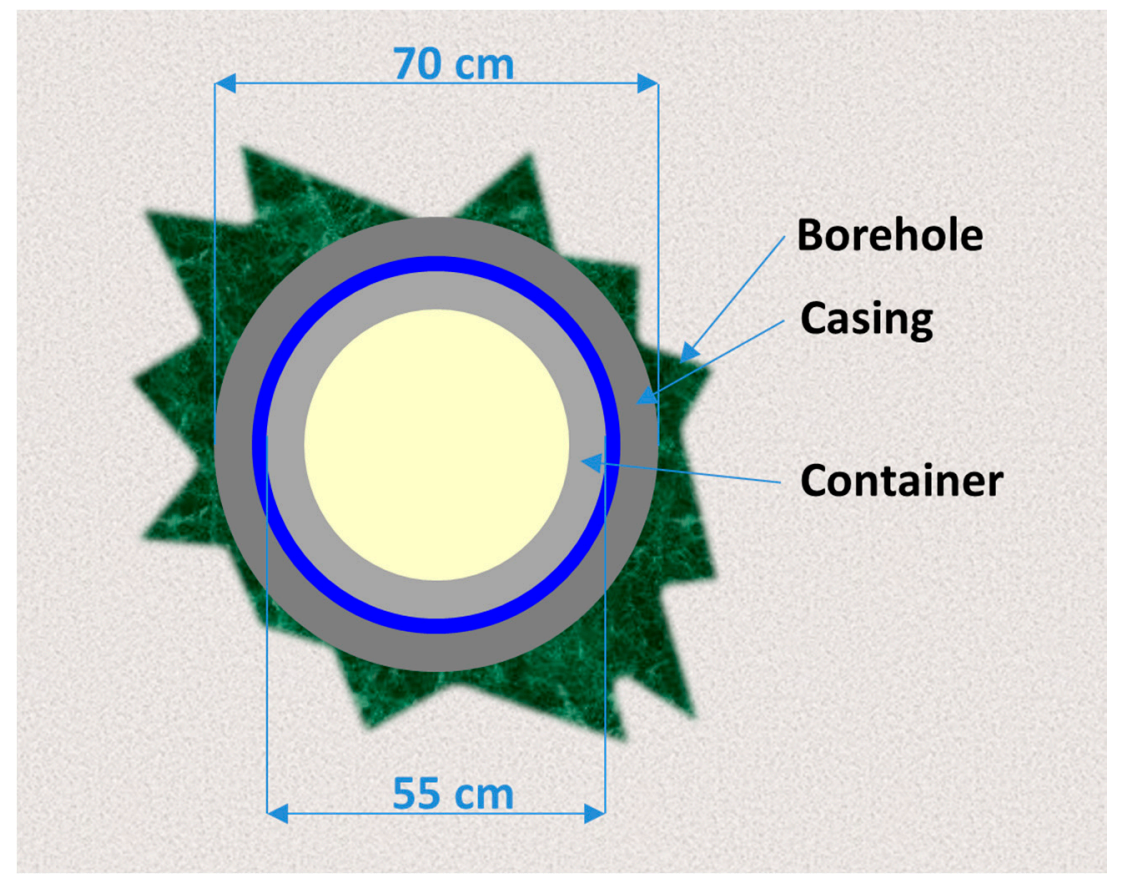

Figure 3. Section of a borehole with casing and container DBC-R.

Table 1. Disposal depth, DBC-R per borehole and number of boreholes.

\begin{tabular}{ccc}
\hline Disposal Depth & DBC-R per Borehole & Number of Boreholes \\
\hline $1500-3500 \mathrm{~m}$ & 356 & 31 \\
\hline
\end{tabular}

\section{Boreholes and Drilling Technology}

Technical feasibility and costs of drilling are important factors for disposal in geological formations [13]. Drilling technologies are used at conventional and unconventional oil and gas production, in geothermics and mining. Experience is also available from experimental drilling and research.

The standard diameter of boreholes ranges from $\mathrm{cm}$ to $\mathrm{m}$ (which is then called shaft sinking in greater depth). In commercial wells, small diameters are usually preferred. As DBD of waste containers requires diameters of $55 \mathrm{~cm}$, the borehole diameter must be larger at the disposal depth (Table 1) compared to those used in oil and gas production. Physical constraints have to be considered, as boreholes become wider and deeper.

For what are termed dry boreholes, the pressure difference between outside and inside the boreholes notably increases with depth and the differential stresses can be so high that boreholes may collapse. This differential stress is lowered if the boreholes are filled with a fluid. The hydrostatic pressure of the fluid column within the borehole reduces the pressure difference acting on the walls of the borehole or the casing. In open boreholes it also counteracts inflow from fluid-bearing permeable lithologies during drilling. For this purpose, the density of the drilling fluid is adjusted to ensure that the hydrostatic pressure within the borehole is always slightly higher than in the surrounding rocks. However, in the case of highly permeable lithologies or rocks with a fracture permeability caused by the drilling operation itself, the drilling fluid may flow and be lost into the surrounding lithologies, leading to a local reduction in normal stresses and finally to failure and breakout of the borehole walls. 
To avoid such flow and loss of the drilling fluid and to reduce the risk of borehole wall failure and breakout, drilling fluids may by loaded with additives like clays (creating a liquid casing), which impedes the flow of the drilling fluid into the rocks. In cased boreholes, the casing precludes flow and loss of borehole fluids into surrounding rocks and the borehole fluids fulfill their mechanical borehole stabilization function.

Thus, geomechanical stability is a limiting factor for the diameter and the depth of boreholes. This is relevant during site selection. The in situ stress field has to be observed when setting the trajectory of the borehole to avoid the failure of the wall of the borehole.

Using drilling fluids (drill mud), boreholes can be drilled safely to great depths as shown by the status of technology and experience from more than 100,000 boreholes for oil and gas in different geological formations. Larger diameters were realized in research drillings (see, e.g., [14]) than in the oil and gas industry. Segmental logging of boreholes gives information on lithology, porosity, conductivity, the density of the formation, and rock alterations in the vicinity of the wall of each borehole.

Most drilling technologies use a drilling fluid which stabilizes the borehole during the drilling phase, facilitates drilling and transports the drill cuttings to the surface. In addition to stabilization with drilling fluid, boreholes are completed with several steel casings which prevent wall collapse and inflow, and which separate different hydrological layers. The casings- to a great extent-are cemented between the outside of the casing steel cylinder and the rock or the inner side of the next larger casing cylinder. The composition of this fluid may vary. After well completion, the drilling fluid is usually replaced by a borehole fluid with different characteristics. Cementation of the casing is usually required.

\subsection{Borehole Design}

Boreholes are cased in order to reach the desired depth for disposal safely by drilling. The detailed design of the casing set is based on subsurface data such as formation pressures, rock strengths, wellbore orientation and stress field.

The borehole drilled must be large enough to accept the casing string and to allow room for cement between the outside of the casing and the hole. A wellhead is usually installed on top of the first casing string after it has been cemented in place.

The inside diameter of the casing must be large enough for the next drill bit to fit into it to continue drilling. Thus, each casing string has a progressively smaller diameter.

Casing design for each size is performed by calculating the worst conditions that may be faced during drilling and production. Mechanical properties of designed pipes such as collapse resistance, burst pressure, and axial tensile strength must be sufficient for the worst conditions that may be encountered at the specific drill site.

Casing strings are supported by casing hangers that are set in the wellhead.

The minimum diameter of a borehole with casing for disposal is approximately $75 \mathrm{~cm}$ assuming DBC-R-containers with canisters of vitrified waste. The safety margin against collapse and other criteria should be provided by the casing and by the container. Therefore, the wall thickness of the casing for disposal was set $6 \mathrm{~cm}$ to cover corrosion, to prevent collapsing and to ensure stability in general. The wall thickness need to be optimized.

The experience of long-term stability and tightness of borehole casings covers more than 100 years. More recent experience is provided by the drillings at the KTB site [14], Groß-Schönebeck [15], Großbucholz [15], Urach [16], Soultz-sous-Forets [11], Gravberg [17] and Kola SG 3 [18], which are publicly documented. These wells have reached much greater depths than considered here in the concept for DBD, but exhibit smaller diameters.

Figure 4 shows the casing set of the KTB site, which was drilled approximately 25 years ago. The outer diameter of the casing with $44.5 \mathrm{~cm}$ at $3000 \mathrm{~m}$ is close to the diameter of the DBC-R of $55 \mathrm{~cm}$ shown in the red rectangle. A casing with a diameter of $70 \mathrm{~cm}$ is considered feasible. 


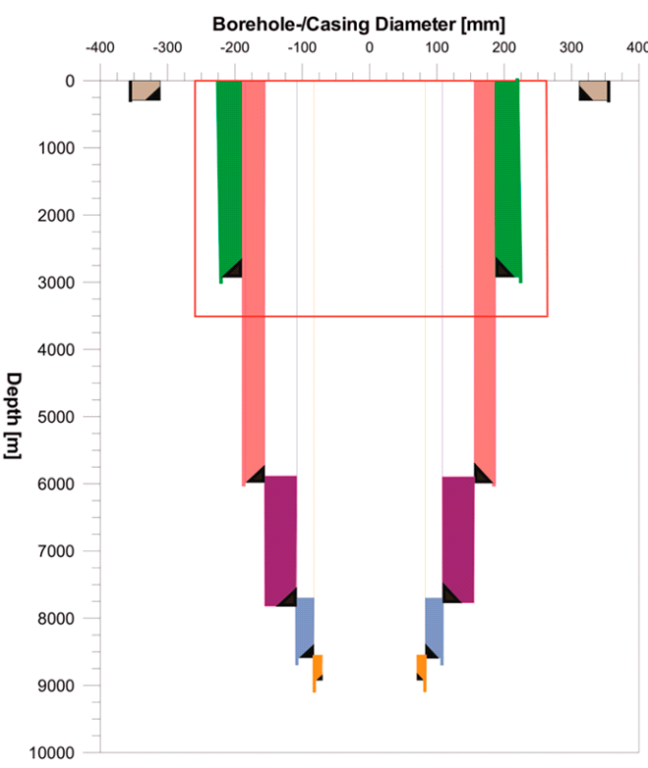

(a)

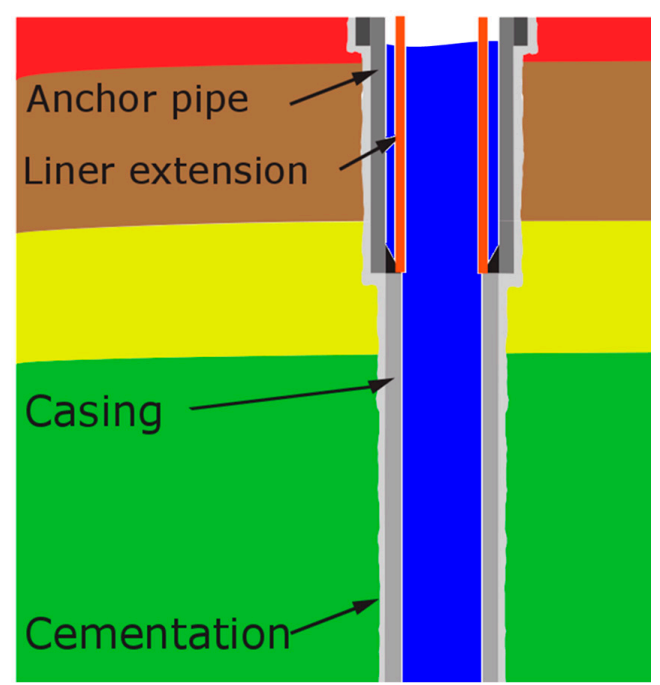

(b)

Figure 4. Schematic casing of the KTB site (a) and sketch with liner extension (b).

\subsection{Drilling and Logging}

The most widely used method is rotary drilling. Oil well drilling utilizes tri-cone roller, carbide embedded, fixed-cutter diamond, or diamond-impregnated drill bits to wear away at the cutting face. This is preferred because when there is no need to return intact samples to the surface for assay by the oil and gas industry. Sizable machinery is used, allowing the penetration of depths of several kilometers. Rotating hollow drill pipes carry down bentonite- and barite-infused drilling muds to lubricate, cool, and clean the drilling bit, to control downhole pressures, to stabilize the wall of the borehole and to remove drill cuttings. The mud returns back to the surface around the outside of the drill pipe, called the annulus. Examining the returning drill mud and the cuttings extracted from the mud is known as mud logging. Another form of well logging is based, e.g., on electrical or sonic pulses or detection of natural radioactive decay and is frequently employed to evaluate the existence of possible oil and gas deposits in the borehole. This can take place while the well is being drilled, using "Measurement While Drilling tools", or after drilling, by lowering measurement tools into the newly drilled hole.

Deviated boreholes currently reach $10 \mathrm{~km}$ lateral distance to the wellhead and are frequently used, especially in offshore drilling.

It was concluded that with today's readily available technology, drilling can be done with a diameter of $43.2 \mathrm{~cm}\left(17^{\prime \prime}\right)$ down to $5000 \mathrm{~m}$ [19]. Since current drilling technology in the oil and gas industry aims for diameters as small as possible to reduce costs, research and development is necessary to generate drilling technology for standard larger diameters down to $3500 \mathrm{~m}$ in depth. The expert assessment is that borehole diameters up to $75 \mathrm{~cm}$ at $3500 \mathrm{~m}$ are already feasible with enhanced technology today $[6,13]$.

\subsection{Distance of Boreholes}

A drilling fluid and a cemented casing are necessary for drilling and operational safety aspects during disposal. The diameter of a borehole including casing was assessed to be $75 \mathrm{~cm}$ for a disposal depth from 1500 to $3500 \mathrm{~m}$. Calculations show that a distance of $50 \mathrm{~m}$ between disposal boreholes should be sufficient to exclude mutual thermal and other effects. The horizontal section of such a borehole field and thus the impact to landscape and land use is relatively small (Figure 5). 


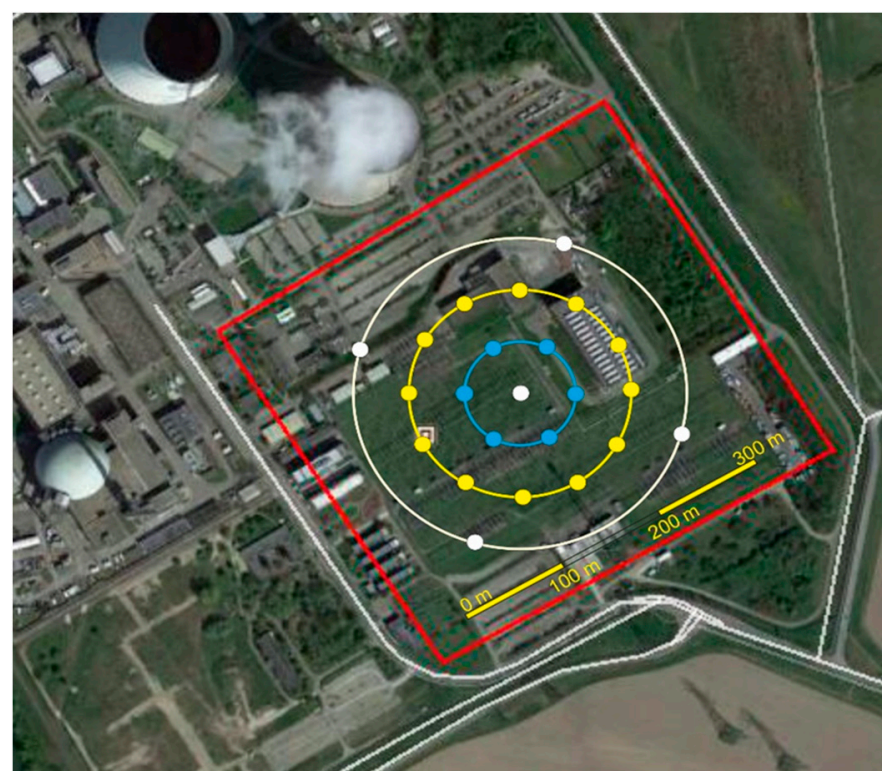

Figure 5. Cross section area for 18 boreholes including boreholes for monitoring (white).

\subsection{Disposal Operation}

Disposal is planned for a zone where all geological barriers are functional (Figure 6). This disposal zone is called the designated zone and has a safety distance to the geological barriers. The zone where at least one of the multiple geological barriers is fully functional and therefore containment can be provided is called the retention zone. The transfer zone is located above the topmost geological barrier.

During disposal operations, any container to be removed from the biosphere has to pass through the transfer zone. It is obvious that technical measures have to ensure safety for the biosphere and the transfer zone, as is the case for any other disposal technology.

The complete borehole is cased and cemented. After installation of the cemented casing, the drilling fluid can be replaced by a borehole fluid specifically designed for disposal operations. Solid-free borehole fluids are used in order to allow recovery during the phase of operation for disposal. This borehole fluid should be compatible with the casing and containers to minimize or inhibit corrosion, have a sufficient density to ensure borehole stability, a suitable viscosity, and should have a low complexing ability for radionuclides.

At least two casings are intended within the biosphere (subject of protection) and the transfer zone. An additional casing (liner extension), which is not cemented, is installed for disposal and represents a safety feature within the subject of protection and transfer zone, reaching down to the retention zone, where a safe disposal of containers can be performed. This liner extension can be removed completely with a sticking container (Figure 6). A hydraulic gate allows recovery of any contaminated borehole fluid.

After disposal, each individual container may be separated by plugs from following disposal operations. Replacing the borehole fluid by cement minimizes fluid volumes. Methods of pumping cement between and around waste packages have not been considered because there is no return path for fluid and care must be taken not to overpressure a waste package with pumped cement. Furthermore, the long-term stability of cementitious materials cannot be guaranteed under the expected prevailing conditions. 


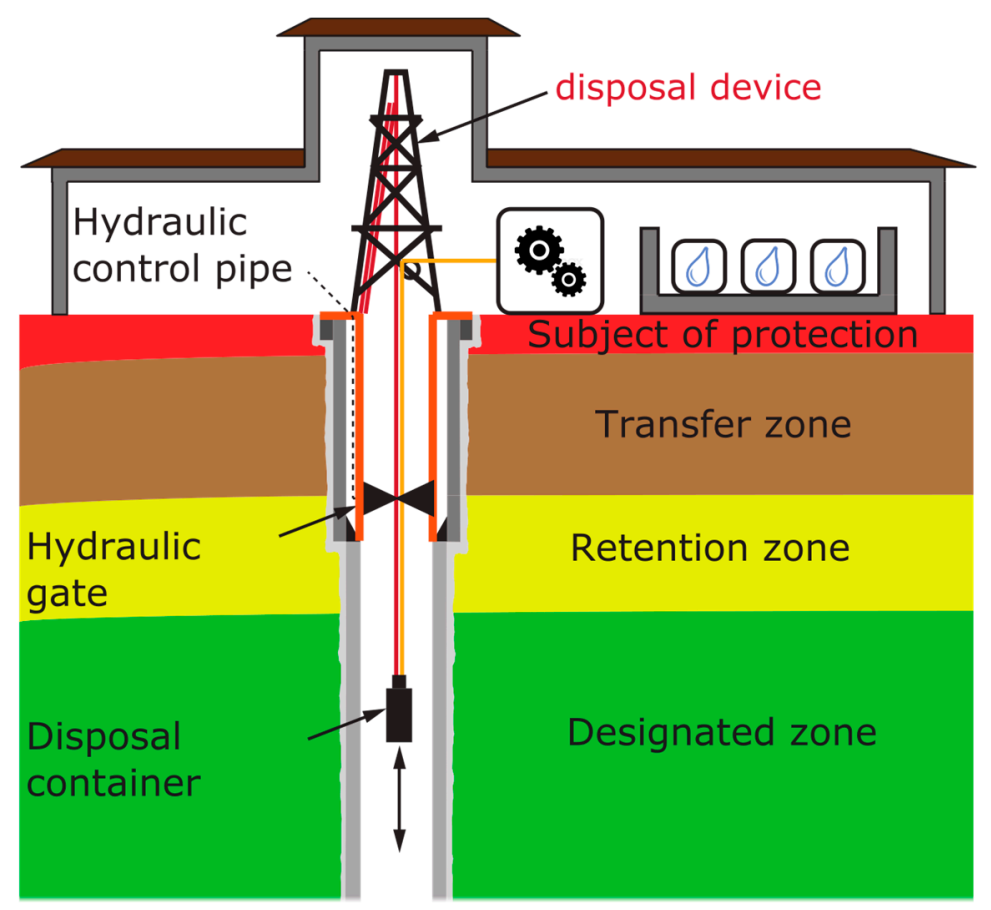

Figure 6. Borehole and disposal operation.

\subsection{Safety of Disposal Operations}

The available disposal technologies are wireline, drill string, coiled tubing, free fall (within a relatively dense borehole fluid) and liner emplacement modes for instruments of any kind. The main differences to the conventional oil and gas industry are the remote, personnel-free operation of the transfer and the huge loads in waste disposal containers compared to probes. A disposal technology for containers in shallower boreholes has already been demonstrated successfully in principle [20].

The proposed containers DBC-R are not self-shielding by design. Therefore measures for radiation protection have to be prepared and a detailed design of such a facility for the emplacement in deep boreholes should be developed to comply with radiation protection during operations. The technical concept for an emplacement facility should include completely encased surface facilities and the borehole with its casings to comply with regulations for nuclear facilities. The container should be delivered in a transfer cask through a lock to the disposal facility and connected to a wireline, drill pipe or coiled tube for disposal. An additional backup (e.g., wireline) could serve as a further safety measure, although a free fall in the borehole is considered possible. When the container is connected to the string, the lock can be opened to lower the container into the well. The descent of each container is slowed down hydraulically by the borehole fluid, which shields radiation (Figure 6). Displaced borehole fluid is collected in a dedicated tank. The fluid is monitored for contaminants and radionuclides. The container is released from the emplacement string when the final disposal position is reached. The emplacement string is removed and monitored for contamination after the disposal of each container. The facility should run in automatic mode so that no personnel are required close to the HLRW. The safe emplacement has to be demonstrated.

In case of container sticking in the transfer zone, the liner extension will be removed with the container. If there is a release of radionuclides to the borehole fluid, the hydraulic gate can be closed and the contaminated fluid can be removed. Measurement devices have to be installed to detect any contaminations with radionuclides within the fluids and spilled fluids.

The design of the containers need not be self-shielding, but should be aerosol tight for a period of 500 years after emplacement. This is required with the objective to facilitate safe recovery [2]. The present design of the container using steel will inevitably lead to some corrosion due to the 
presence of water (as a constituent of the borehole fluid) and the high temperature in the disposal zone. Therefore, further research and development is necessary on the subject of container design for borehole disposal, when recoverability is to be ensured.

Provided that the borehole exists and is ready for disposal, there is no need for dedicated research on installation of rigs or on transportation of loads for disposal since this is standard technology. If deviating boreholes are intended, a high inclination near vertical should be planned to minimize the friction of containers during emplacement.

\subsection{Borehole Seals}

After completion of disposal and cementation of the well within the designated zone, boreholes should be fully sealed and abandoned. Borehole seals should ensure that there is no intrusion of groundwater into the disposal zone and that no contaminants from the disposal zone are released towards the subjects of protection via the boreholes. The seals shall re-establish the main characteristics of the geological barriers drilled through. Sealing of the borehole may be achieved in several ways with materials of proven long-term stability (salt, clay, bitumen) and over the entire length of the borehole. A favorable method for sealing a borehole utilizes the creep behavior of salt rock at greater depth and thus higher temperature [21], which is intended in the concept.

Figure 7 shows a cased borehole (1) which is reamed completely including removal of the casing in the salt formation; (2) due to the relatively small diameter of the borehole, the high temperature (above $100{ }^{\circ} \mathrm{C}$ ) and high pressure of the salt rock, the salt creeps within hours or days; (3) and the borehole is sealed effectively along its reamed length; (4) the sealing process may be enhanced and supported by filling the reamed section with crushed rock salt or molten salt.

Comparable sealing operations can also be performed in clay formations. Due to the slower visco-elastic behavior of clay and clay-rich rocks, here bituminous seals and high-density clay suspension could be used. There are materials that have proven their long-term stability over millions of years in the subsurface.

Proven technologies can be used, as it is standard to seal and to monitor boreholes for all kind of drilling operations (abandonment).

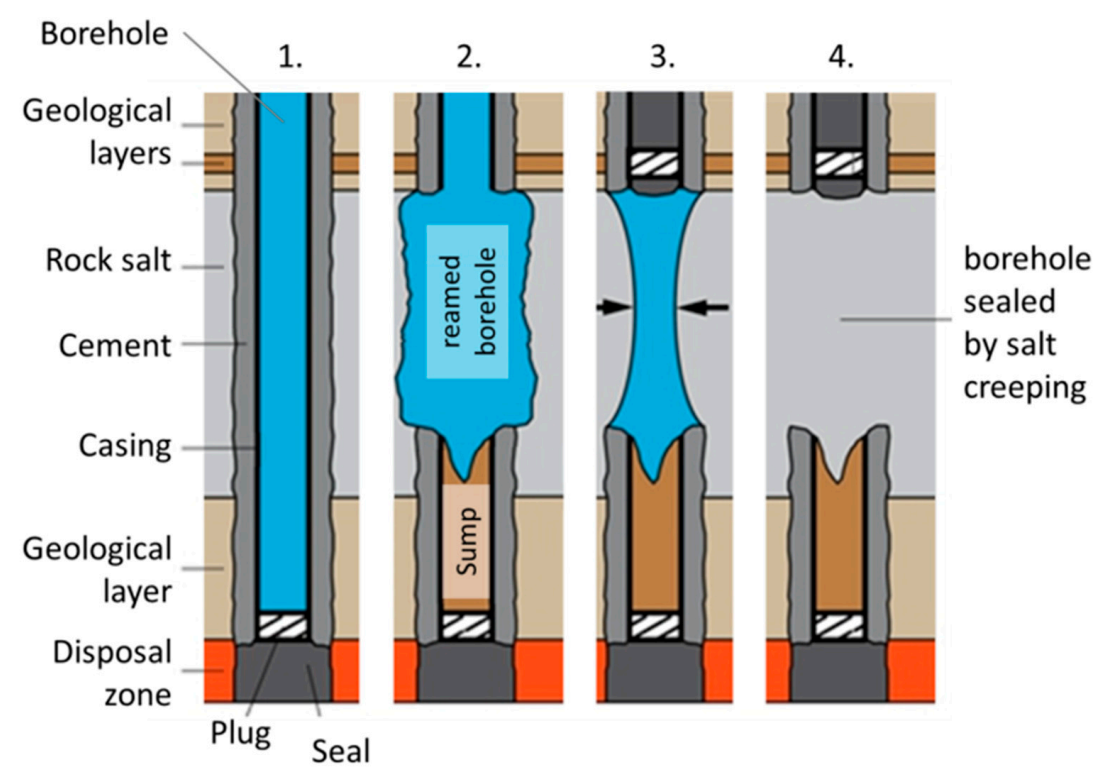

Figure 7. Steps of borehole sealing (geology not to scale, modified after [21]). 


\section{Site Selection Criteria and Safety Assessments}

Disposal in geological formations using mining technology with retrievability and recoverability is favored [8]. It is also noted that disposal using boreholes in geological formations is the only realistic alternative option over transmutation or long-term interim storage. If disposal in deep boreholes should be a possibility in Germany, the concept and the selected site have to comply with German safety requirements [2], which are currently under revision. Furthermore, a site selection procedure with (preliminary) safety assessments for DBD is required [8].

The containment-providing rock zone (CPRZ) is a key element of the safety requirements [2]. The concept for borehole disposal can take advantage of multiple geological barriers such as clay or salt rock layers, which can be used to define multiple and different possible CPRZs of types A (enclosure of waste by CPRZ in the host rock) or Bb (large lateral extension of CPRZ overlying the waste in the host rock) [22], besides others [12]. If disposal takes place directly in a salt or clay formation, type A is possible. Disposal in a crystalline rock should have at least a CPRZ of type Bb if no containment is provided by host rock or technical barriers [8].

A schematic sketch for disposal in deep boreholes is shown in Figure 8. The general methodology for safety assessments—which is also discussed in [8] — should be adapted in some of the technical details (e.g., shaft or drift seals could be seen as equivalent to borehole seals).

Any assessment will be based on the safety requirements [2] (under revision) and will make analogous use of the requirements and criteria for site selection for geological disposal in a mine given by [8]. The technically important requirements for site selection have exclusion, minimum and weighting geo-scientific criteria.

Although these requirements and criteria of [8] are intended to be applied to sites in geological formations using a mined repository, they are discussed here for application to a concept using deep boreholes for disposal, or whether, to be applicable, an adaptation of the requirements and criteria should be considered. Specific criteria for DBD are not available currently.

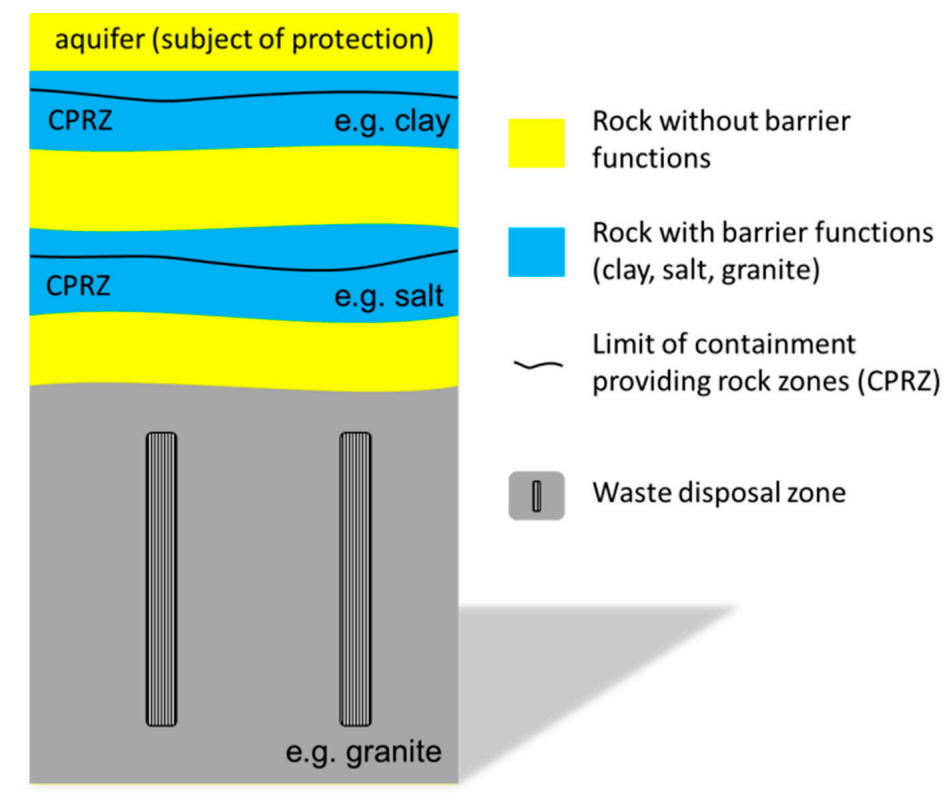

Figure 8. Possible containment-providing rock zones (CPRZ) for borehole disposal.

\subsection{Geo-Scientific Requirements and Criteria for a Mined Repository Applied to Deep Borehole Disposal}

The geo-scientific criteria for exclusion (large scale vertical movements, active faults, impact from mining, seismic and volcanic activity, age of groundwater) can be applied directly to the concept of DBD since this is also disposal in a geological formation. 
The minimum geo-scientific criteria (permeability of formation, thickness of the CPRZ, depth of CPRZ, disposal area, period for proof) can be applied to the concept of DBD in the same way as for a mined repository, considering that the location of the CPRZ does not need to coincide with the location of the disposed waste.

Eleven weighting geo-scientific requirements in three groups [8] have to be discussed: quality of containment and reliability of its evidence; validation of containment; and additional safety-relevant features (Tables 2-4).

All requirements are assessed using the generic concept for DBD. At a later stage, a site-specific assessment of the criteria is required. For the disposal in deep boreholes, some weighting criteria can be fulfilled favorably by adhering closely to the definition of the CPRZ and host rock. Since in the generic concept of the DBD the CPRZ is not part of the host rock of the disposal zone but part of the overlying geological barriers, some criteria for safety-relevant features should be applied to other rocks as well (e.g., No. 4 of Tables 2 and 3). A favorable weighting seems to be possible, but relative only to the underlying generic concept of DBD and applying it to the CPRZ.

Two requirements (No. 2 and 3 of Table 4) have been assessed as not applicable to DBD. The temperature will be higher than the temperature limit of $100{ }^{\circ} \mathrm{C}$, which has been requested as a precautionary measure, and gas generation can take place to some extent. In any case, the temperature criterion has been disputed heavily [8,23-25].

Two requirements (No. 4 and 5 of Table 4 ) are recommended for reassessment for applicability to DBD. The requirement to have a high retention capability of CPRZ for radionuclides could be extended to other rock formations available below the CPRZ of the DBD concept. The requirement for favorable hydrochemistry should be reassessed for the host rock to be useful in DBD since containment is not provided in the disposal zone.

Table 2. Requirements of weighting group 1: Quality of containment and reliability of its evidence.

\begin{tabular}{cll}
\hline No. & \multicolumn{1}{c}{ Requirement } & \multicolumn{1}{c}{ Comment } \\
\hline 1. & $\begin{array}{l}\text { No or slow transport with groundwater in } \\
\text { the CPRZ }\end{array}$ & $\begin{array}{l}\text { Can be fulfilled depending on the definition and size } \\
\text { of the CPRZ of the overlying rocks (salt/clay layer). }\end{array}$ \\
\hline 2. & $\begin{array}{l}\text { Favorable configuration of rock body, host } \\
\text { rock and CPRZ }\end{array}$ & $\begin{array}{l}\text { Can be fulfilled depending on the definition and size } \\
\text { of the CPRZ of the overlying rocks (salt/clay layer) } \\
\text { and host rock. }\end{array}$ \\
\hline 3. & Good spatial characterization & $\begin{array}{l}\text { Can be fulfilled depending on the definition and size } \\
\text { of the CPRZ of the overlying rocks (salt/clay layer). } \\
\text { Tools to characterize host rock properties are } \\
\text { available for greater depths. }\end{array}$ \\
\hline 4. & $\begin{array}{l}\text { Good predictability of the long-term } \\
\text { stability of favorable conditions }\end{array}$ & $\begin{array}{l}\text { Can be fulfilled depending on the definition and size } \\
\text { The rock formation relevant for assessment of the } \\
\text { permeability should be defined. }\end{array}$ \\
\hline
\end{tabular}

Table 3. Requirements of weighting group 2: Validation of containment.

\begin{tabular}{lll}
\hline No. & \multicolumn{1}{c}{ Requirement } & \multicolumn{1}{c}{ Comment } \\
\hline 1. & Favorable rock mechanics & $\begin{array}{l}\text { Can be fulfilled depending on the definition and } \\
\text { size of the CPRZ of the overlying rocks (salt/clay } \\
\text { layer). The host rock formation relevant for } \\
\text { assessment of the rock mechanics is in the } \\
\text { disposal zone. }\end{array}$ \\
\cline { 2 - 3 } & $\begin{array}{l}\text { Can be fulfilled depending on the definition and } \\
\text { size of the CPRZ of the overlying rocks (salt/clay } \\
\text { layer). The host rock formation relevant for } \\
\text { assessment of the groundwater flows is in the } \\
\text { disposal zone. }\end{array}$ \\
\hline
\end{tabular}


Table 4. Weighting group 3: Further safety relevant features.

\begin{tabular}{|c|c|c|}
\hline No. & Requirement & Comment \\
\hline 1. & $\begin{array}{l}\text { Protective composition of } \\
\text { overlying rocks }\end{array}$ & $\begin{array}{l}\text { A number of geological units with different but favorable characteristics, } \\
\text { including additional redundant or diverse barriers, are possible in the } \\
\text { generic concept due to depth of CPRZs and disposal zone. }\end{array}$ \\
\hline 2. & $\begin{array}{l}\text { Good conditions to avoid or } \\
\text { minimize gas generation }\end{array}$ & $\begin{array}{l}\text { The present concept for container and casing intends steel, which will } \\
\text { inevitably lead to some gas generation. Gas generation may be minimized } \\
\text { or slowed down by choice of suitable borehole fluid or cementation of } \\
\text { containers. A future concept may also minimize the use of steel or may } \\
\text { provide physical gas traps underneath the CPRZ. Gas generation cannot be } \\
\text { completely avoided in the generic concept. }\end{array}$ \\
\hline 3. & Good temperature compatibility & $\begin{array}{l}\text { The temperature in the disposal zone will already be higher than } 100^{\circ} \mathrm{C} \\
\text { due to the depth. It is therefore not a criterion for site selection and not } \\
\text { applicable or useful for DBD. }\end{array}$ \\
\hline 4. & $\begin{array}{l}\text { High radionuclide retention } \\
\text { capability of CPRZ }\end{array}$ & $\begin{array}{l}\text { Can be fulfilled depending on the definition and size of the CPRZ of the } \\
\text { overlying rocks (salt/clay layer). Other rock formations could be relevant } \\
\text { for assessment and should be defined. These criteria should also be } \\
\text { re-evaluated for other rock formations and the host rock of the } \\
\text { disposal zone. }\end{array}$ \\
\hline 5. & Favorable hydrochemistry & $\begin{array}{l}\text { Can be fulfilled depending on the definition and size of the CPRZ of the } \\
\text { overlying rocks (salt/clay layer) which is not part of the host rock. } \\
\text { Other rock formations could be relevant for assessment and should be } \\
\text { defined.This criterion should also be re-evaluated for other rock formations } \\
\text { and the host rock of the disposal zone. }\end{array}$ \\
\hline
\end{tabular}

\subsection{Safety Analysis and Assessment}

Safety analyses should be done to assess operational safety and the long-term safety of DBD. A recent preliminary safety analysis on a generic concept showed good retention of radionuclides [26]. However, [26] did not consider all possibly relevant processes (gas flow, groundwater flow through faults, fractures and the excavation damaged zone (EDZ)). Therefore a more detailed operational and long-term safety analysis and assessment of the generic concept of DBD for Germany, as well as for specific sites, has yet to be performed [9].

\subsection{Retrievability/Recoverability}

The general requirement for reversibility in the site selection process was set in [8]. On the one hand, this concerns the site selection process itself; on the other, it also has some technical implications which concern retrievability and recoverability of disposed waste.

Retrievability is the planned technical option for removing emplaced radioactive waste containers from the repository facility during its operational phase. This is also required by [2]. The containers and the borehole must allow retrieval until sealing and closure of the boreholes. This relates to the decision of whether closure means a single borehole, a borehole field or all boreholes. At this stage, the understanding is that disposal in a borehole can be performed within a few years and the borehole is then sealed and closed. Based on experience in conventional drilling, it was assessed that retrieval of containers should be possible during a timeframe of at least five years after closure.

Recovery is the retrieval of radioactive waste from a final repository as an emergency measure after the operational phase is over. This emergency may happen after the borehole is closed. A time period of 500 years was required for a possibility to recover waste containers [2]. The understanding is that the container and the casing should be designed to survive this time period without releasing radioactive contaminants or aerosols. Experience on recovery of lost objects in conventional drilling covers 100 years, but does not include recovery of corroded containers with HLRW.

Whereas, from the experts' perspective, retrievability seems to be manageable once the borehole and casing exists, recoverability from deep boreholes needs some research and development to show if it is feasible. 


\subsection{Hazards}

Hazardous incidents during the operational phase might cause significant releases of radionuclides. Whereas volcanoes, earthquakes and other hazardous geological events should be excluded as far as possible using the site selection criteria, some operational incidents nevertheless need to be assessed.

An incident might be a crack in the wall or break of a single container during disposal and subsequently the spent fuel or glass might get into contact with the borehole fluid. Dissolution of the glass or an instant release or radionuclides from spent fuel would contaminate the borehole fluid. The amount of released radionuclides would depend on the contact time of fluid and waste and on the composition of the waste package. Therefore, measures for retrieval and repair should be provided and comply with radiation protection regulations.

A worst case, which should be unlikely, would be the loss of container within the subject of protection which cannot be retrieved for some reason. A release of radionuclides takes place in the longor short-term and has to be assessed taking account of the geochemical and hydrological conditions.

The long-term safety analysis should consider that the containers currently proposed for DBD are not corrosion-resistant in the long term with respect to groundwater at disposal depth. Even if corrosion may take place slowly, some hydrogen gas generation and other corrosion processes will occur. This may increase the pressure within the sealed borehole and may impact the transport of released radionuclides. Heat generation and high temperatures in the disposal zone will speed up chemical processes, which cannot be modelled in detail due to a lack of thermodynamic data.

The total mass of fissile radionuclides in a deep borehole will be above the critical mass. Therefore possible critical excursion and safety measures have to be assessed. Although preliminary safety analysis excluded critical excursions due to the low solubility and mobility of U(IV), an assessment and optimization should be performed.

\section{Research and Development}

Boreholes with diameters of $0.75 \mathrm{~m}$ at $3500 \mathrm{~m}$ in depth are still beyond today's standard technology, but are considered feasible. Based on this, a concept for disposal of radioactive waste in deep boreholes is drafted. Further development and demonstration of dedicated borehole technology is necessary to demonstrate routine technical feasibility.

The goal of disposal with recoverability also necessitates research and development into the long-term behavior of the container and casing in great depth with elevated temperatures.

The operational phase for disposal of radioactive waste in deep boreholes requires investigations in detail about its safety and radiation protection. There is a need for development, testing and demonstration. This includes the feasibility of retrieval before closure.

If the current proposal of the Commission about recoverability for 500 years remains a prerequisite, it would emphasize the need for research and development on containers and technology.

\section{Summary and Conclusions}

Using deep boreholes for disposal (DBD) of high-level radioactive waste (HLRW) can have advantages for long-term safety due to an ample distance between the HLRW and the biosphere (subject of protection), and may take advantage of multiple geologic barriers as safety features. The great depth and short duration of disposal operations would also efficiently impede proliferation. Finally, aside from the site selection process, there may be a time-related benefit for technical implementation and for the costs of implementation.

A generic concept for DBD of HLRW has been developed, applying containment-providing rock zones (CPRZ). Although further technical developments are required for HLRW disposal in deep boreholes to address larger than usual borehole diameters and depths, DBD seems to be feasible as an alternative option to geological disposal of radioactive waste. Further research and development with 
a feasibility demonstration is necessary. Operational and long-term safety analyses and assessments have to be performed.

On the one hand, a major challenge for DBD is the requirement for possible recovery of waste for 500 years after closure. On the other hand, if disposal is intended to be a permanent and the safest solution, recovery might not be the main focus of the decision when highest possible safety is desired. During policy decision-making, if there are clear advantages for long-term safety with DBD, these might outweigh the disadvantage with recovery.

The favorable depth for DBD based on the shown generic concept ranges from 1500 to $3500 \mathrm{~m}$. Based on the current state of knowledge in drilling technology, it was assessed that the required diameter for disposal of high-level radioactive waste at this depth can be operated. A deeper disposal of HLRW may appear better, but the increasing technical challenges may outweigh this.

DBD's advantages in safety, speed, and perhaps in cost were shown and discussed. DBD might be seen as a possibility for geological disposal in Germany. To have this option available as a proven technology during a policy decision, it seems very sensible to follow up the DBD concept with the installation of a real-scale demonstration along with a detailed operational and long-term safety analysis. DBD could then provide technical redundancy-if required—in case the siting or implementation of a mined repository fails or cannot be pursued any longer for some reason. Once DBD is established it could also be used in countries which have low volumes of radioactive waste.

Acknowledgments: The underlying study [9] was funded by a contract with the commission on "Storage of high-level radioactive waste" which permitted further publication. The cost to publish in open access was covered by GRS gGmbH.

Author Contributions: Guido Bracke compiled the publication and drafted the section on site selection criteria and safety assessment; The concept was drafted by Frank Schilling and Guido Bracke; Frank Charlier designed the DBC-R and disposal operation; Axel Liebscher and Thomas Röckel contributed to boreholes and drilling technology. All authors discussed the results and commented on the manuscript.

Conflicts of Interest: The authors declare no conflict of interest.

\section{References}

1. Gomm, H. Endfassung für Konzept D im FESAE-Projekt. Endlagerung von Brennelementen in Tiefbohrungen; Kavernen Bau-und Betriebs-GmbH: Hannover, Germany, 1982.

2. German Federal Ministry of the Environment, Nature Conservation and Nuclear Safety (BMU). Safety Requirements Governing the Final Disposal of Heat-Generating Radioactive Waste; BMU: Bonn, Germany, 2010.

3. Nuclear Waste Technical Review Board (NWTRB). Technical Evaluation of the U.S. Department of Energy Deep Borehole Disposal Research and Development Program. A Report to the U.S. Congress and the Secretary of Energy; NWTRB: Arlington, VA, USA, 2016.

4. Hardin, E.; Peretz, F.; Adeniyi, A.; Nogradi, P.; Su, J.; Cochran, J.R. Conceptual design for waste packaging and emplacement in deep boreholes. In Proceedings of the International High-Level Radioactive Waste Management Conference, Charlotte, NC, USA, 9-13 April 2017; pp. 818-825.

5. Rigali, M.J.; Hardin, E.L.; Stein, E.R.; Su, J.-C. Large diameter deep borehole disposal concept for HLW glass. In Proceedings of the International High-Level Radioactive Waste Management Conference, Charlotte, NC, USA, 9-13 April 2017; pp. 536-546.

6. Gibb, F.G.F.; Beswick, A.J.; Travis, K.P. Deep borehole disposal of nuclear waste: Engineering challenges. In Proceedings of the ICE-Energy; ICE Publishing: London, UK, 2014; Volume 167, pp. 47-66.

7. Bracke, G.; Hurst, S.; Merkel, B.; Müller, B.; Schilling, F. (Eds.) Proceedings of the Workshop "Final Disposal in Deep Boreholes Using Multiple Geological Barriers: Digging Deeper for Safety" Juni 2015, Berlin; Köln, Germany, 2016. Available online: http://www.grs.de/sites/default/files/pdf/grs-405_neu_red.pdf (accessed on 12 July 2017).

8. Kommission Lagerung hoch radioaktiver Abfallstoffe. Abschlussbericht der Kommission Lagerung hoch radioaktiver Abfallstoffe (K-Drs. 268); Berlin, Germany, 2016. Available online: https://www.bundestag. de/blob/434430/bb37b21b8e1e7e049ace5db6b2f949b2/drs_268-data.pdf (accessed on 12 July 2017). 
9. Bracke, G.; Charlier, F.; Geckeis, H.; Harms, U.; Heidbach, O.; Kienzler, B.; Liebscher, A.; Müller, B.; Prevedel, B.; Röckel, T.; et al. Tiefe Bohrlöcher (K-Mat 52); Köln/Garching b. München/Berlin/Braunschweig, Germany, 2016. Available online: https://www.bundestag.de/blob/ 413166/73c4148a71bb98611305958662204e23/kmat_52-data.pdf (accessed on 12 July 2017) and http://www. grs.de/sites/default/files/pdf/grs-423.pdf (revised version, accessed on 13 July 2017).

10. Deutsche Erdöl AG (DEA). Rekordbohrung Erschließt Mittelplate-Öl. Available online: http://www. mittelplate.de/de/press-releases/rekordbohrung-erschliesst-mittelplate-ol (accessed on 12 July 2017).

11. Tischner, T.; Pfender, M.; Teza, D. Hot Dry Rock Projekt Soultz: Erste Phase der Erstellung einer wissenschaftlichen Pilotanlage: Abschlussbericht zum BMU-Vorhaben; Hannover, Germany, 2006. Available online: http://www.whymap.org/DE/Themen/Energie/Downloads/soultz_abschlussbericht. pdf?_blob=publicationFile\&v=3 (accessed on 17 July 2017).

12. Park, Y.-J.; Sudicky, E.A.; Sykes, J.F. Effects of shield brine on the safe disposal of waste in deep geologic environments. Adv. Water Resour. 2009, 32, 1352-1358. [CrossRef]

13. Beswick, J.A. Borehole construction and operation for disposal in crystalline rocks. Radwaste Solut. 2017, 24, 28.

14. Engeser, B. Das kontinentale Tiefbohrprogramm der Bundesrepublik Deutschland. Bohrtechnische Dokumentation; Niedersächsisches Landesamt für Bodenforschung: Hannover, Germany, 1996.

15. Kwiatek, G.; Bohnhoff, M.; Dresen, G.; Schulze, A.; Schulte, T.; Zimmermann, G.; Huenges, E. Microseismic event analysis in conjunction with stimulation treatments at the geothermal resarch well GTGRSK4/05 in Groß Schönebeck/Germany. In Proceedings of the Thirty-Third Workshop on Geothermal Reservoir Engineering Stanford University, Stanford, CA, USA, 28-30 January 2008.

16. Tenzer, H.; Schanz, U.; Homeier, G. HDR research programme and results of drill hole Urach 3 to depth of $4440 \mathrm{~m}$-The key for realisation of a HDR programme in southern Germany and northern Switzerland. In Proceedings of the World Geothermal Congress 2000, Beppu-Morioka, Japan, 28 May-10 June 2000.

17. Juhlin, C.; Wallroth, T.; Smellie, J.; Eliasson, T.; Ljunggren, C.; Leijon, B.; Beswick, A.J. The Very Deep Hole Concept-Geoscientific Appraisal of Conditions at Great Depth; Swedish Nuclear Fuel and Waste Management Co.: Stockholm, Sweden, 1998.

18. Fuchs, K.; Kozlovsky, Y.A.; Krivtsov, A.I.; Zoback, M.D. Super-Deep Continental Drilling and Deep Geophysical Sounding; Springer Science \& Business Media: New York, NY, USA, 2012.

19. Arnold, B.W.; Brady, P.V.; Bauer, S.J.; Herrick, C.; Pye, S.; Finger, J. Reference Design and Operations for Deep Borehole Disposal of High-Level Radioactive Waste; SAND2011-6749; Albuquerque, NM, USA, 2011. Available online: http:/ / prod.sandia.gov/techlib/access-control.cgi/2011/116749.pdf (accessed on 12 July 2017).

20. Filbert, W.; Bollingerfehr, W.; Heda, M.; Lerch, C.; Niehues, N.; Pöhler, M.; Schulz, J.; Schwarz, T.; Toussaint, M.; Wehrmann, J. Optimization of the Direct Disposal Concept by Emplacing SF Canisters in Boreholes. Abschlussbericht zum FuE-Vorhaben "Optimierung der Direkten Endlagerung durch Kokillenlagerung in Bohrlöchern"; 02E9854, TEC-10-2009-AB; DBE Technology GmbH: Peine, Germany, 2010.

21. Kretzschmar, H.J.; Schmitz, S.; Schreiner, W.; Lendel, U. Salzstopfen-Versatz von CO2-Speicherbohrungen. Erdöl. Erdgas. Kohle 2009, 125, 440.

22. Arbeitskreis Auswahlverfahren Endlagerstandorte (AkEnd). Site Selection Procedure for Repository Sites. Recommendations of the AkEnd-Committee on a Site Selection Procedure for Repository Sites; Arbeitskreis Auswahlverfahren Endlagerstandorte (AkEnd): Köln, Germany, 2002.

23. Reichert, B. Stellungnahme zur öffentlichen Anhörung des Umweltausschusses am 08.03.2017 zur Fortentwicklung des StandAG; Ausschussdrucksache 18(16)526-L; Deutscher Bundestag, Ausschuss für Umwelt, Naturschutz, Bau und Reaktorsicherheit: Berlin, Germany, 2017. Available online: https:/ /www.bundestag.de/blob/496262/84893a9bb6185b53ea9bf0a8b219a9d6/18-16-526-1_anhoerung standag_prof_dr_barbara_reichert-data.pdf (accessed on 13 July 2017).

24. Röhlig, K.-J. Stellungnahme anlässlich der öffentlichen Anhörung zu dem Entwurf eines Gesetzes zur Fortentwicklung des Gesetzes zur Suche und Auswahl eines Standortes für ein Endlager für Wärme entwickelnde radioaktive Abfälle und anderer Gesetze; Ausschussdrucksache 18(16)526-H; Deutscher Bundestag, Ausschuss für Umwelt, Naturschutz, Bau und Reaktorsicherheit: Berlin, Germany, 2017. Available online: https:/ / www.bundestag.de/blob/495598/be7a30efb777af9bf8eed327040585bb/18-16-526-h_anhoerung standag_prof_dr_klaus-juergen_roehlig-data.pdf (accessed on 12 July 2017). 
25. Watzel, R. Stellungnahme zur öffentlichen Anhörung des Umweltausschusses am 08.03.2017 zur Fortentwicklung des StandAG; Ausschussdrucksache 18(16)526-G; Berlin, Germany, 2017. Available online: https: / /www.bundestag.de/blob/495596/f8ddf3330a486ffab12f8a245ba8a569/18-16-526-g_anhoerung standag_bgr-data.pdf (accessed on 13 July 2017).

26. Arnold, W.B.; Brady, P.; Altman, S.; Vaughn, P.; Nielson, D.; Lee, J.; Gibb, F.; Mariner, P.; Travis, K.; Halsey, W.; et al. Deep Borehole Disposal Research: Demonstration Site Selection Guidelines, Borehole Seals Design, and RDED Needs; SAND2013-9490P; FCRD-USED-2013-000409; Washington, DC, USA, 2013. Available online: https://www.energy.gov/sites/prod/files/2013/12/f5/ DeepBorehDisposalRDDemoSiteGuideDesignSealsNeeds.pdf (accessed on 12 July 2017).

2017 by the authors. Licensee MDPI, Basel, Switzerland. This article is an open access article distributed under the terms and conditions of the Creative Commons Attribution (CC BY) license (http://creativecommons.org/licenses/by/4.0/). 